\title{
Workers, Education, and Social Change in Brazil
}

\author{
William J. Mello
}

Indeed the interests of the oppressors lie in changing the consciousness of the oppressed, not the situation which oppresses them, for the more the oppressed can be led to adapt to the situation the more easily they can be dominated.

$$
\text { --Paulo Freire, Pedagogy of the Oppressed }
$$

\begin{abstract}
This article examines how Brazilian labor organizations developed educational programs that simultaneously confronted the issues of large scale illiteracy, particularly among young workers, while at the same time seized the opportunity to educate new generations of social movement and labor activists. Specifically, it explores the educational program Projeto Integrar, organized by the National Confederation of Metalworkers (CNM/CUT), and its importance for the broader process of political transformation presently underway in Brazil.
\end{abstract}

Keywords: Social movements, unions, education, Latin America

Over the past two decades, Latin America and Brazil in particular have undergone deep sociopolitical transformations driven by a process of substantial economic growth and the consolidation of democratic governance. While most of the globe has suffered a long term economic crises since 2008 (Mello, 2008; Queiro-Tajalli, 2010); in Brazil, the consequences of the crisis have been slight compared to the effects experienced in the United States and Europe. For example, in Brazil, large-scale employment and state redistributive measures have helped significantly reduce historic, large-scale poverty and income inequality over the past few years. The current success of many Latin American countries is due in large part to the emergence and continuous re-election of left-led governments. In Brazil, this process is illustrated by the emergence of the Partido dos Trabalhadores (PT) /Workers Party, first with the election of president Luis Inácio Lula da Silva for two terms starting in 2003, and currently under the presidency of Dilma Rouseff, the country's first woman president.

The popular support enjoyed by the Workers Party reflects the expansive influence of social and labor movements, such as the Movimento dos Trabahadores Sem Terra (MST) /Landless Peasant Movement (Sem Terra Magazine, 2007), as well as a myriad of labor unions and left-led political parties. Over time, the convergence of social forces helped develop the conditions for deep-rooted social change. While many acknowledge the importance of strong social and labor movements in transforming contemporary Latin America, one aspect of change rarely examined is the influence of educational programs organized by social movements and labor organizations. These programs seek to expand the political and social consciousness of workers and provide education for future generations of working class activists.

William J. Mello, Ph.D., is an Associate Professor, Indiana University School of Social Work, Department of Labor Studies, IU Northwest campus.

Copyright (C) 2013 Advances in Social Work Vol. 14 No. 1 (Spring 2013), 1-12 
In 1996, the Confederação Nacional de Metalúrgicos (CNM/CUT) / Brazilian National Confederation of Metalworkers affiliated with the Central Workers Council / Central Única dos Trabalhadores (CUT), initiated Programa Integrar (Lopes, 2006), a radical educational program that proposed to advance working class political influence in society. Integrar contested prevailing notions of how and why workers were educated in Brazil. In a broad sense, the program was a response to elite ideological domination within the context of an increasingly privatized educational structure. At the same time, Integrar sought to expand labor's participation in deciding the future of education in Brazilian society.

Integrar is a counter-hegemonic movement and therefore part of a larger struggle for the social and political consciousness of the Brazilian working class. The union's educational program helps increase labor's role in deciding public policy issues. Many of Brazil's social movements have developed educational programs that not only provide primary and secondary education, but, in the process, form future social activists whose work moves beyond the scope of the organized labor movement. The Brazilian metalworker's experience in education provides an important resource for understanding the role labor unions play in building vibrant and influential social movements in Latin America.

This article is a case study that draws on the authors' multiple trips to Brazil; observing adult education classes and visiting with program organizers, participants, and political and community activists. The research also explores literacy data from the Ministry of Education of the Brazilian Government and the Central Workers Council, as well as pedagogical reviews of Integrar by Brazilian academics in the field of education.

\section{Literacy and Social Change}

Addressing large-scale illiteracy in Brazil is a monumental undertaking. It is a pervasive social problem that reflects years of elite domination and a fragmented public educational system that fails to provide equal access to schools and universities. Even taking into consideration the current government's attention to the problem, Brazilian authorities recognize the insidious existence of large-scale illiteracy. According to government study reports the illiteracy rate in 2003 was $11.6 \%$, which is a $32 \%$ reduction, from the 1992 illiteracy rate of 17.2\%. Even so, the current rate represents an expressive sector of the population, approximately 14.6 million Brazilians. Moreover, illiteracy among the Brazilian population is clearly delineated by region, class, race, and gender. For example, in 2003, the illiteracy rate in the northeastern region of the country was 3.4\% higher than the industrialized region of the southeast (Secretaria de Educação Continuada, Alfabetização e Diversidade (SECAD), Ministério de Educação Programa Brasil Alfabetizado, 2005). Current census results illustrate that coinciding with the country's economic growth, Brazil continues to experience a decline in illiteracy rates, particularly among youth and adults under 60 years of age. According to the 2010 general census, there was a significant decline in illiteracy among the population 15 years or older from 13.63\% in 2000 to 9.6\% in 2010 (Instituto Brasileiro de Geografia e Estatística, IBGE, 2010). 
The primary focus of the educational program, Integrar concerns the unemployed adult population and is a response to the country's expansive illiteracy rates and the imposition of global neoliberalism on the economy. A recent government survey indicated that the illiteracy rate among the population between 50 and 64 years was almost 7 times greater than among young people (age 15-24), and that when race was considered, illiteracy was almost $2.5 \%$ greater among blacks than whites, indicating that two thirds of the illiterate population was black (Secretaria de Educação Continuada, Alfabetização e Diversidade (SECAD), Ministério de Educação Programa Brasil Alfabetizado, 2005).

Integrar was organized as a response to long periods of economic recession, high levels of unemployment, and historically elevated illiteracy rates among the working class population. These conditions placed severe constraints on the battle for union organization and working class political power. Global neoliberal transformations of the Brazilian economy set in place at the onset of the 1990s introduced rapid technological changes in the workplace, along with large-scale poverty. This process led to the marginalization of significant sectors of the working class from political and socioeconomic processes. Marginalization, in this context, is understood as the social exclusion of considerable sectors of the working class and their subsequent alienation. In this process, workers are not only constrained politically; but as a result, the development of working class political consciousness is curtailed as well. Marlene Goldenstein (2002) argues that: "The flexible and precarious nature of work destroys social rights and does not create alternatives... there is a shift in how poverty is conceived from the public and political sphere to the non-political, where poverty is viewed as a fact to be resolved through purely technical measures or through private philanthropy” (p.18).

For the metalworker's union, the education and literacy of workers could not simply replicate existing norms and parameters that prepare workers for the global workplace; to do so would legitimize the process of marginalization. Education and the program's pedagogical methods were viewed as a singular process that raised the social and political consciousness of workers, while simultaneously preparing them to advance their demands in the sphere of politics.

An important aspect of the program argued that the struggle against marginalization and the demand for social inclusion were integral aspects of a process essential for expanding working class power. In this sense, education was not viewed as charitable work for the underprivileged. For the metal workers union, education was the backdrop for the deep ideological conflict emerging in contemporary society between market and non-market views of socioeconomic development. Freire argues,

Admitting the existence of men 'outside of' or 'marginal to' structural reality, we may legitimately ask: who is the author of this movement from the center of the structure to its margin? Do so-called marginal men, among them the illiterates, make the decision to move out of the periphery of society? ...Alienated men, they cannot overcome their dependency by 'incorporation' into the very structure responsible for their dependency. There is no other road to humanization - theirs 
as well as everyone else's - other than the authentic transformation of the dehumanizing structure. (1970, p. 48)

In this context, marginalization was not just an economic casualty of global economic restructuring; it was the result of social and political alienation inherent to capitalist development. Incorporating the victims of socioeconomic and political marginalization into the political process seemed critical because the logic of neoliberal globalization led disenfranchised sectors of the working-class to adopt the logic of capital. As a result, workers failed to recognize those responsible for large-scale poverty and subsequently placed the burden on those who were in fact its victims. In this process, workers internalized their long-term unemployment as a personal failure rather than viewing it as a systemic effect of elite domination.

Similarly, social inclusion was not simply the reintroduction of marginalized sectors of society into the very structure which led to their marginalization. The re-entry of workers into the productive process was an important moment in the political process where alternative socioeconomic models of organization expanded the power of those currently relegated to the fringes of the prevailing social structure. Consequently, this process strengthened popular organizations, among which unions figured prominently. As a result, education and political activism developed concomitantly and interfaced in multiple spheres of social engagement.

\section{Social Change and Working Class Education}

In order to better understand the comprehensive underpinnings of Integrar, both politically and methodologically, it is important, even if only briefly, to revisit the basic pedagogical concepts developed by Paulo Freire (1970). In a broad sense, Freire's pedagogical concerns were a response to elite domination. He saw the transformative role of education as a process for building critical consciousness among politically disenfranchised sectors of the population. He drew extensively on the notion of education as a dialectical relationship where the interrelations between subjective and objective consciousness are central conditions for social change. For Freire, education was a political-pedagogical process where individual and collective critical awareness were essential for social transformations, and where non-elites increasingly expanded their political power (Scocuglia, 2003). Critical consciousness, in this way, is not just knowledge, but more importantly, the way in which knowledge is achieved and the subsequent action it elicits. Freire (1970) argues, to achieve critical consciousness of the facts, that it is necessary to be the "owner of one's own labor," that labor "constitutes part of the human person," and that "a human being can neither be sold nor can he sell himself" is to go a step beyond the deception of palliative solutions. It is to engage in authentic transformation of reality in order, by humanizing that reality, to humanize men (p.185).

An essential aspect of Freire's political-pedagogical project focused on the role of the learner and a classroom that acted as an extension of the broader socio-political process underway. In this process, learning is not devoid of what is occurring in society, rather it requires a deep understanding of the context in which both learner and educator live and 
work. He argued that education begins by initiating a dialogue between learners and educators where they talk to each other rather than at each other. As a result of this dialogue, social location, conflict, problems, and the life experiences of learners and educators are all important aspects to learning.

Dialogue becomes an intricate part of learning; it is a measure of critical consciousness. The process of social transformation occurs when learners increasingly gain greater understanding of their role in the world around them through the intersection of the subjective and objective conditions of their situation in society (Freire, 1985). Education is a continuous process of building consciousness that links knowledge to the broader struggle for political freedom. Freire (1985) noted that,

For man this process of orientation in the world can be understood neither as a purely subjective event, nor as an objective or mechanistic one, but only as an event in which subjectivity and objectivity are united. [sic] Orientation in the world so understood, places the purposes of action at the level of critical perception of reality. (p.44)

In his view, pedagogy takes on broad implications and stands as a political alternative that contests elite domination, socioeconomic hierarchies, and the perceived invincibility of global neo-liberal forces predominant in present-day society.

With the mounting pressures of global neo-liberalism shaping all aspects of working class life, developing pedagogical approaches that contest growing economic inequality and corporate control of everyday life, and help expand the political power of social movements is an increasingly important task for organized labor. The development of class-based alternatives to the prevailing logic of capital helps workers break away from conformity and domesticity, and in the process, develop an alternative to the prevailing socioeconomic process.

By the mid-1980s, rapid neo-liberal, socioeconomic, and political transformations in Brazil, juxtaposed against the backdrop of historically high levels of income inequality and an enduring return to democracy, brought to the forefront the demands for working class power in very direct ways. Building labor's political power implied blocking the predatory process of global neo-liberal reforms that were redefining the basic structure of society.

For the union, the education of the working-class in its multiple formats was a strategic issue present in the most crucial of labor's political battles and vital for the future of the Brazilian labor movement. Education was a process through which workers expanded their role as citizens and activists, organized, mobilized, and subsequently strengthened their capacity to influence the political decision-making process. The program expanded organized labor's constituency to broad sectors of the working-class (not just union members), developing class consciousness and the critical mass necessary to advance labors' political and economic demands. 


\section{Integrar Program}

\section{Educate for Labor Militancy}

The inception of Integrar reflected a broader notion of class and labor militancy adopted by significant sectors of the labor movement in the struggle against the military dictatorship from 1964 to 1985. The program was conceived to widen the scale and scope of traditional labor education and apprenticeship programs that had been in place for some time, moving the targeted audience from the limited membership role of the unions to the notion of workers as a class within society. Fernando Lopes (2006), Adjunct General Secretary of the International Federation of Metalworkers explained:

The experiences of the union movement are not new. In the seventies many training schools were open... These schools were aimed at training militants so that they could be better prepared to carry on organizational work in the plants. There was little public involvement in these activities and with the expansion of the workers movement these activities were relegated to a secondary level. Whatever their ideological position, unions offered skill training to their members in the same way they offered barber shops and dental clinics. (p.1)

In this sense Integrar breaks with traditional models of union education and the structural-ideological constraints that limit working class organization. The program assumes a fundamental importance in a country where illiteracy and social exclusion are major constraints to socioeconomic development.

The program rapidly grew both structurally and politically. Four years after its inception, in 1996, Integrar expanded from a primary education and literacy program to a comprehensive educational and training institute; training workers, union activists, social movements, cooperatives, and popular organizations. Basic instruction was just one of the many activities developed by the Metal Workers Confederation. The institute provided courses for organizing cooperatives, administration, economics, politics, and society; and linked the daily lives of workers to the larger struggle for socioeconomic justice and equality.

Integrar was financed through a combination of public funds provided by the Ministry of Education, and state and local governments. Unions, in particular are eligible to receive federal funds from the Ministry of Labor through a program called FAT (Fundo de Amparo ao Trabalhador- Workers Support Fund), specifically developed to support labor's educational activities.

\section{The Pedagogy of Class}

The organizers of Integrar argue that the battle for class hegemony occurs in three essential spheres of society: on the shop floor, in the larger political organization of society, and in the struggle to shape public policy. In this way the program's political objectives are the basis for the pedagogical organization of the project. Integrar is comprised of three basic educational programs: Integrar for Employed Workers (Programa Integrar para Trabalhadores (as) Empregados), Integrar for Unemployed 
Workers (Programa Integrar para Trabahadores (as) Desempregados), and Integrar for Union Leadership Training (Programa Integrar Formação de Dirigentes). The course disciplines are not organized as distinct subjects examined individually; instead students complete modules that draw intermittently on the various disciplines.

Each of the programs has program-specific political-educational objectives that shape the curriculum content and practicum. For example, the objectives of Integrar for Employed Workers focus on building workers' knowledge of the production process, developing the collective action of workers, and expanding worker power at the point of production. The political-pedagogical objectives of Integrar for Unemployed Workers focus on creating alternative forms of generating income, economic solidarity, and expanding the influence of the union among broad sectors of the unemployed, both young and old. Finally, the pedagogical objectives of Integrar for Union Leadership Training, centers its attention on reinforcing working class organization on the shop floor, enhancing the political-ideological capacity of workers, and shaping public policy by strengthening labor's strategic alliances with broader sectors of society (Formação na Ótica dos Trabalhadores).

According to the programs organizers approximately 300,000 workers have participated in one or more of the many courses organized by Integrar. Most of the courses are held in union halls, union vocational training schools, and community centers. The program's primary education course is one year in duration, divided into segments of 25 hours per week, for 100 hours per month, for a total of 800 hours. The secondary education program is two years in duration, similarly with segments of 25 hours per week, for a total of 1600 hours. Considering the extreme poverty faced by many of the programs' participant-learners, everyone receives textbooks and other educational material at no charge, as well as daily bus passes to ensure their presence in the classroom.

The concept of an integrated education is not just a method through which knowledge is delivered, but a process of enhancing a learner's critical view of society. The curriculum draws on the major questions that define working class life such as unemployment, cost of living, political rights, and organization, as well as the workers' particular life experiences. In this process, students are active participants in building a body of knowledge and not just passive recipients of information. Learners quickly realize a clear and useful purpose to the study of math, science, economics, social studies, and history, and the relation between their education and their daily struggles.

Students are provided pedagogical materials such as textbooks that address the methodological and political concerns of the program, so that all modules have a defined yet continuous flow of content. Some of the textbooks used in the modules are: The Economy and Social Exclusion, Transformations of the World of Work and Modern Civilization, Social Relations and Work in Brazil, and Work, Race and Inequality.

\section{Pedagogy and Structure}

The program's basic activity provides primary, secondary, and professional education for workers, young and old, independent of union affiliation or employment status. A 
fundamental aspect of the program re-conceptualizes the curriculum content of primary and secondary education, restructuring the way in which workers learn. The core curriculum questions what knowledge is and how critical thinking is developed, reinforcing the correlation between learning and broader social, economic, and political transformations under way in Brazil. The primary objective of the program is not simply the transference of information, but the development of a participatory citizenry. Integrar provides the necessary wherewithal through which workers expand their power in society and reinforce the structures of participatory democracy, both locally and nationally.

The basic principles of Integrar are useful in understanding the program's fundamental political objectives and mission:

Political Objectives:

1. It is the obligation of the state to guarantee a free and quality public education.

2. Public resources must be invested in activities that support working-class interests.

3. Unemployment is the result of the current model of political-economic development and not an individual problem or a lack of qualification.

Mission:

1. Coordinate the articulation between education and action to strengthen the notion of citizenship and the labor movement.

2. Articulate the process of professional and basic education.

3. Elevate the value of workers' acquired knowledge. (Maia, 1999)

\section{Teaching Social Change}

The program's organizers argue that education is a process of political literacy where both educator and student must remove themselves from their traditional roles, to free the process of education from its domesticating tendencies. Freire points out: "Education for domestication is an act of transferring 'knowledge,' whereas education for freedom is an act of knowledge and a process of transforming action that should be exercised on reality" (1970, p. 102). The fundamental objective of education is the transformation of people from the objects of history to the subjects of history. This radical transformative process does not exist in a world different from the one in which we live, nor is there a neutral approach to the object of study. The process of education does not occur devoid of societal influences and constraints, nor do students and educators exist in isolation from the prevailing socioeconomic structure (Freire, 1985).

Action is an important aspect of the learning process; that is, real learning is demonstrated by the participant's capacity to translate their intellectual understanding into concrete action. A particularly important aspect of the program's methodological structure is that the communication and debate of ideas at the center of the learning process is not limited to speech and writing. Knowledge can be ascertained through 
various mediums: art, music, dance and cinema; even physical education is considered a form of communication. For example, the instruction of communication skills is introduced in various disciplines and is not just the responsibility of the language instructor (Mascellani, 1999).

Rather than delivering strictly delimited areas of knowledge, such as math, history, etc. like that in traditional schools, subjects are infused into pedagogical units where the learning process develops by integrating multiple areas of knowledge into a single module. Learning occurs in phases developed concomitantly over the course of the modules' presentation. By adopting this methodological practice, the program's participants develop an understanding that there is a crossover of subject matter and that the acquisition of knowledge occurs in many forms and moments, using multiple mediums, and the results of which are measured in both intellectual and practical ways.

\section{Evaluation as a Component of Learning}

Another critical aspect of the program's educational structure is the use of pedagogical evaluations as permanent aspects of the learning process. Continuous evaluations are an important part of building a body of knowledge for both students and educators. Evaluations allow all those involved in the process to continuously measure the effectiveness of the program, recognize problems, and make changes to modules already in progress. Consequently, much like the program's methodological structure, systemic and continuous evaluations are an intricate aspect of the learning process that allows educators and students alike to reach their defined goals.

Integrar's evaluation process is based on the comparative examination of learning through the lens of the program's objectives. It is a critical and self-critical process between students and educators measuring individual and collective participation in the program (Mascellani, 1999). In the evaluation process students and educator critically examine course content and delivery as well as a self critical anaysis of the participants. In this process student success is measured by reaching the objectives set out in the initial class. Individual intellectual developments, as well as general capacities of students collectively are the parameters used to determine success.

\section{Labor's Politics and Public Policy}

The political resolutions approved at the metalworkers' convention in the early 1990s argued that the fundamental conflict in Brazilian society was the contradiction between two competing political projects: on one side, the political agenda of "capital and large corporations," and in the opposite camp, working class political interests allied with small- and mid-sized entrepreneurs. Integrar coordinator Marco Aurelio Spall Maia (1999) pointed out,

[...their analysis acknowledges] a dispute for the hegemony of society and as a result of this dispute the need for unions to expand working class political interests. To achieve these goals the union's activity should focus on two major courses of action, both of which are distinct and complimentary components of the larger struggle to transform society. First, expand the unions' effective 
involvement in the general political struggles of public policy issues, such as agrarian reform, employment, industrial policies, economic reform, social security, and education, healthcare, housing, professional training among others should be placed at the forefront of the unions concerns. It was within this logic that Integrar began. (p. 31)

The strategic objectives of Integrar seek to reinforce the political interests of workers and reflect a broader transformation in the day-to-day work developed by unions. State and local metalworker's unions have expanded their participation to address a broad array of political battles throughout the country. As a result of the unions support for popular social movements, the practice of mutual solidarity among different sectors of the working class has become increasingly visible. For example, in some regions, local metalworker's unions help sustain popular movements such as peasant land occupations and community housing cooperatives. The daily activities of the unions are combined with shop floor activism, and struggles of other sectors of the working class are viewed as part of a larger process of building an alternative working class political project.

On one hand, for the National Confederation of Metal Workers (CNM/CUT), education is a means of building the social consciousness necessary for organization and mobilization. All aspects of learning are an intricate part of an alternative political project that contests the neoliberal political alternatives being imposed on the working class. On the other hand, education, both for unions, as well as for workers in general, is a comprehensive part of labor's struggle for greater political power. For the union, the defense of working class interests in defining the structure of public education is an immediate, as well as a long-term strategic goal. Maia contended,

Both educational programs for unemployed workers and the unions' leadership training programs are indicators that we have surpassed traditional notions of working-class education...education is a continuous process that draws simultaneously on basic knowledge as well as the day-to-day experience of the union as a process that helps define the unions strategic planning and political practices... [in contrast] to the asymmetrical practice of union education with no self-critical analysis, no continuity of content or evaluation of the process. (p. 41)

In this way, the process of building working class political power is achieved by consolidating symmetrical relationships between education, union organization, and political action; they are all components of a singular process with multiple focal points.

In spite of Integrar's expansive undertakings, motivating local and state unions and the unemployed to engage in the strategic educational program has not always been met with success. The daily pressures placed upon unions to respond to the advances of neoliberal political strategies, limited or declining resources and changes in the union leadership have all constrained the program's ability to expand beyond the geo-political constituency of the union and its immediate allies. Moreover, the expansion of the program, after implementation, often requires the re-election of favorable local and state governments. Changes in public administration can lead to discontinued efforts, since many traditional political forces do not view the program's objectives favorably. 
Integrar, as an alternative for working-class education, is not viewed as a substitute to the public education system. The program is an alternative model to the current market driven neo-liberal educational model that is rapidly being introduced. It is a means through which organized labor can intervene in defining the public policy for education while simultaneously advancing broader class political interests.

\section{References}

Freire, P. (2005, 1993,1970). Pedagogy of the oppressed. New York, NY: Continuum Internacional Publishers.

Freire, P. (1985). The politics of education, culture, power and liberation. Westport, CT: Bergin \& Garvey Publishers.

Goldenstein, M. S. (2002). O instrutor do programa Integrar desempregado. (Unpublished Masters thesis). Universidade Estadual de Campinas/Faculdade de Educação, São Paulo.

Instituto Brasileiro de Geografia e Estatística (IBGE) (2010). Population Census. Retrieved from http://www.brasil.gov.br/

Lopes, F. (2006). Program “Integrate:” A proposal for union intervention in questions of employment, development and education. Retrieved from www.integrar.org.br/paginas/ver_textos.asp?49

Maia, M. A. S. (Ed.) (1999). Trabalho, educação e cidadania: Reflexões sobre programa Integrar, RS. Rio Grande do Sul, Brazil: CUT/Integrar.

Mascellani, M.(1999). Procedimentos metodológicos, ensino médio. Rio Grande do Sul, Brazil: CUT/Integrar.

Mascellani, M. (1999). Sistema de avaliação, ensino médio. Rio Grande do Sul, Brazil: CUT/Integrar.

Mello, W. J. (2008). Citizens and activists: Civil society in democratic Brazil. In R. Dibie (Ed.), Civil society in a comparative perspective (pp. 45-63). Washington, DC: Lexington Books.

Queiro-Tajalli, I. (2010). In search of economic and social justice: The Piquetero Movement in Argentina. In W. J. Mello \& T. Iverson (Eds.), Trabalhadores, novas perspectivas e comparações. Fortaleza, Brasil: Editora da Universidade Estadual do Ceara.

Secretaria de Educação Continuada, Alfabetização e Diversidade (SECAD), Ministério de Educação Programa Brasil Alfabetizado (2005). A evolução da Alfabetizaçã de Jovens e adultos e o programa Brasil Alfabetizado. Republica Federativa do Brasil.

Programa Integrar (1998). Avaliação pedagógica. Rio Grande do Sul, Brazil: CUT/Integrar. 
Batista, J., \& da Silva, G. F. (2007, January 24). The peqrspectives and actions of the MST for 2007. Journal dos Trabalhadores Sem Terra Magazine, \#269, January 2007. Retrieved from www.mst.org.br/journal/269

Scoculglia, A. C. (2003). A historia das ideas de Paulo Freire e a Atual Crise de Paradigmas. João Pessoa, Paraíba, Brasil: Editora Universitária João Pessoa.

\section{Author note:}

Address correspondence to: William J. Mello, Ph.D., Associate Professor, Indiana University - School of Social Work, Department of Labor Studies. IU Northwest, 3400 Broadway, Lindenwood, Gary, IN 46408. Email: wmello@iupui.edu 